\title{
NOMENCLATURAL AND CRITICAL NOTES ON SOME BRAZILIAN SPECIES OF Paspalum (POACEAE: PANICEAE).
}

\author{
Tarciso S. FILGUEIRAS ${ }^{1}$
}

\begin{abstract}
A critical analysis of the type collections of 39 species names of Paspalum L. (Poaceae: Paniceae) from Brazil described by Swallen is presented along with comments based on more recent gatherings of the species. Eighteen new synonyms are proposed.
\end{abstract}

Key words: Gramineae, grasses, nomenclature, Brazil.

Nomenclatural and Critical Notes on Some Brazilian Species of Paspalum (Poaceae: Paniceae).

RESUMO - Apresenta-se uma análise crítica da nomenclatura de 39 nomes de espécies de Paspalum L. (Poaceae: Paniceae) do Brasil, descritas por Swallen. A análise baseia-se no exame das coleçoes típicas e de coletas mais recentes das espécies investigadas. Como resultado desses estudos, 18 novos sinônimos são propostos.

Palavras-chave: Gramineae, gramíneas, nomenclatura, Brasil.

\section{INTRODUCTION}

The elaboration of a checklist of the Brazilian Poaceae, now in progress, made it necessary to critically evaluate the Brazilian species of Paspalum L. published in Swallen's last paper (1967). For many decades several of those names puzzled botanists dealing with Brazilian grasses. The descriptions supplied by Swallen are generally very brief, and in most cases, they provide no clues as to the affinity of the species described. This inevitably led many agrostologists to wonder whether the variations described were really discrete or could they be encompassed within the range of variation of previously described taxa. The present study aims at addressing precisely this question, i.e., the circumscription of the taxa described by SWALLEN (1967).

\section{MATERIALS \& METHODS}

The type collections of the Brazilian species of Paspalum described by SWALLEN (1967) were examined at the Smithsonian Institution herbarium (US) and at the Missouri Botanical Garden (MO). Also more recent gatherings of the species under investigation deposited at IBGE, MO, SP, UB and US were examined. The acronyms of the herbaria cited follow HOLMGREN et al. (1990).

In his last paper SWALLEN (1967) described 56 new species, 54 from Brazil, 2 from Colombia, and 1 from Venezuela. Most of the species were assigned to informal groups such as Livida, Notata, Recta, etc., and sequentially numbered ( 1 to 58 ), but a few remainded "ungrouped." The grouping of individual species to

1 Reserva Ecológica do IBGE, Caixa Postal 08770, 70312-900 Brasilia, DF, Brasil. Bolsista do $\mathrm{CNPq}$. 
groups is not dealt with in this paper. However, the same sequence numbers in Swallen's paper are used. All the Brazilian species are treated herein, except species number $27,31,32,33,34$, $35,36,38,39,40,41,42,43,45$, and 46 which are currently being studied by Dr. J.F.M. Valls (CEN).

\section{RESULTS AND DISCUSSION}

1. Paspalum spissum Swallen, Phytologia 14: 358. 1967.

Type. Brazil: Maranhão, rocky hill, Carolina to San [Santo] Antonio [Antônio] de Balsas, 20-25 March, 1934, J.R. Swallen 4050 (US!).

This species is similar to $P$. carinatum Humb. \& Bonpl.,differing however by having leaves that are both basal and cauline, villous basal leaves and flat leaf blades $2-5 \mathrm{~mm}$ wide.

2. Paspalum nitidum Swallen, Phytologia 14: 358. 1967.

Type. Brazil: Santa Catarina, Sao Francisco do sul, Monte Crista, Garuva, 3 March 1961, R. Reitz \& R. M. Klein 10900 (US 2383777, n.v:; photograph US!). $=$ P. pumilum Nees, fide Smith et al. 1982.

The holotype could not be found at US. According to staff members it may be considered "missing, temporarily misplaced." The examination of the only paratype available (R. Reitz \& R.M. Klein 5200) together with a photograph of the holotype, coupled with the information in the protologue suggests that the description of $P$. nitidum was based on a depauperate specimen of $P$. pumilum. SWALLEN (1967) distinguished these species on the basis of foliage pubescence and spikelet size. However, specimens collected in the same area as the holotype (e.g. Klein 10368,10397 , US) bridge the alleged gap between these species because the leaves vary from glabrous to glabrescent to densely pilose on both surfaces, and spikelet sizes also vary within the limits found in P. pumilum.

The plant height in this species is quite variable throughout its range in Brazil (from Amapá to Rio Grande do Sul). For example, in Glaziou 4307(US), from Rio de Janeiro, they are from $4-10 \mathrm{~cm}$ tall, whereas those in Smith \& Klein 15793(US), from Santa Catarina, are $9-19 \mathrm{~cm}$; in Clayton \& Eiten 4705 (MO) from São Paulo, the culms are $58-60 \mathrm{~cm}$ tall. It was synonymized under $P$. pumilum by Smith et al.(1982) who provided no clue as to how their conclusion was reached.

3. Paspalum pisinnum Swallen, Phytologia 14: 360. 1967.

Type. Brazil: Piaui, between Fazenda Nacional and Picos, 4-5 April 1934, J.R. Swallen 4217 (holotype US 1613175 !). Syn. nov. $=P$. denticulatum Trin.

The description of $P$. pisinnum was based on a depauperate plant of $P$. denticulatum with the appearance of an annual or a weak perennial. The racemes and spikelets are entirely glabrous, as in $P$. denticulatum. No reliable characteristic was found to set it apart as a distinct species. 
4. Paspalum trinii Swallen, Phytologia 14: 360. 1967.

Type. Brazil: Ceará, Cratheús [Crateús], 9-10 May 1934, J.R. Swallen 4507(holotype US 1613382!), Syn. nov. $=$ P. denticulatum Trin.

The description of $P$. trinii was based on a plant of uncertain longevity, i.e., it may be considered a fairly robust annual or a weak perennial. The general appearence is that of $P$. denticulatum. The culms reach ca. $70 \mathrm{~cm}$ in height; there are $9-11$ racemes per culms, the racemes are $1-3 \mathrm{~cm}$ long, and the rachis has a few scattered long, colorless hairs up to $1 \mathrm{~cm}$ long. No reliable characteristic was found to consistently separate $P$. trinii from $P$. denticulatum.

5. Paspalum trichophyllum Henr, Blumea 4: 513, 1941.

Type. Brazil: Pará, Ilha de Marajó, Fazenda Gavinho A. Goeldi 165 (holotype US!), Syn. nov. $=P$. denticulatum Trin.

The holotype is a plant of ca. $35 \mathrm{~cm}$ in height, with basal leaves, leaf blades ca. $7 \mathrm{~cm}$ long and $1-2 \mathrm{~mm}$ wide, racemes $0.5-1 \mathrm{~cm}$ long and rachis with very few scattered colorless hairs. Morphologically it is indistiguishable from the type of $P$. denticulatum, and it is the morphological link between $P$. denticulatum and all the other species in Swallen's Livida group (SWALLEN, 1967).

6. Paspalum goeldii Swallen, Phytologia 14:361, 1967.

Type. Brazil: Pará, Ilha do Marajó, Estate [Fazenda] Gavinho, June 1918, A. Goeldi 197 (holotype
US 1039605 !), Syn. nov. $=P$. denticulatum Trin.

The holotype is a plant similar to the holotype of P. trinii Swallen, but it is a robust perennial, with more than 15 racemes $4-5.5 \mathrm{~cm}$ long. Variation in robustness and number of racemes can be found throughout the range of $P$. denticulatum and appears to be correlated with local ecological conditions.

7. Paspalum denticulatum Trin., Gram. Pan. 111. 1826.

Type. "Amer. aequin.", Sine loco, sine anno, Lindley s.n. (LE, n.v.; MW? n.v.; fragment US!).

According to Chase (unpublished manuscript on Paspalum of South America at US) the type of $P$. denticulatum is in the Trinius Herbarium and bears the name in Trinius' handwriting. Locality and collector are not given. A fragment of the type was examined at US: the rachis is glabrous, green, ca. $1.5 \mathrm{~mm}$ wide, the spikelets are paired, ca. $1.5 \mathrm{~mm}$ long, glabrous. The upper glume and lower lemma are rough, but with a thin texture, fragile, 3-nerved; the glume has denticulate marginal nerves and the upper floret (both lemma and palea) is papillose.

Trinius' original description (1826) of $P$. denticulatum and his illustration of the species (TRINIUS, 1829) were used by me as the basis for the recognition of the species as well as for the proposal of the new synonymy.

8. Paspalum humigerum Swallen, Phytologia 14: 362. 1967.

Type. Brazil: Bahia, Joazeiro, Rio Salitre, 46 Km WSW Joazeiro, 15 
December 1924, A. Chase 7931 (holotype US!; Isotypes MO!, US!;), Syn. nov. $=P$. denticulatum Trin.

The holotype bears the annotation "type" in Swallen's handwriting and is a small, weak plant of indefinite duration, culms $45-50 \mathrm{~cm}$ tall, blades 7 $10,5 \times 0.2-0.3 \mathrm{~cm}$, racemes $5-7,1-$ $2.3 \mathrm{~cm}$ long. There is an isotype in the same folder that matches exactly the holotype of $P$. trinii but is definitely a robust perennial. The culms are ca. 100 $-115 \mathrm{~cm}$ tall; the blades are $12-25 \mathrm{x}$ $0.4-0.5 \mathrm{~cm}$. There are ca, 19 racemes, $1.5-4.5 \mathrm{~cm}$ long. The characteristics of this isotype do not agree with the protologue of $P$. humigerum, but they supplied many of the reasons for merging it into $P$. denticulatum.

9. Paspalum petrosum Swallen, a species from Vaupés, Colombia, is not treated here.

10. Paspalum chapadense Swallen, Phytologia 14: 363. 1967

Type. Brazil: Maranhão, between Caxias and Barra do Corda, 18-26 February 1934, J.R.Swallen 3508 (holotype US!) $=$ P. coryphaeum Trin., syn. nov.

Detailed study of the holotype and of the protologue suggests that there is no morphological difference between $P$. coryphaeum and $P$. chapadense. The holotype of the latter is a fairly robust plant, culms ca. 90 $\mathrm{cm}$ tall, with villous node, lanceolate blades, $25-35 \times 0.8-10 \mathrm{~cm}$, and ca. 28 ascending racemes. The number of racemes vary a great deal on the paratypes (Swallen 3474, 3519, 3562, 3563,3565 , 3566, 3601, US!), i.e., from 4 to 28 , but the spikelets are rather uniform and indistinguishable from those of $P$. coryphaeum.

11. Paspalum dasytrichium Dusén ex Swallen, Phytologia 14:363. 1967. Type. Brazil: Paraná, Villa [Vila] Velha, 21 October 1914, P. Dusén 15700 (holotype US 2302271!).

This species is very similar to $P$. coryphaeum, differing however by the strong rhizome, villous lower nodes and basal sheaths and glaucous leaf blades.

P. dasytrichium var. glabrum L.B. Smith \& Wasshausen, Bradea: 247. 1978. Type. Brazil: Santa Catarina, Mun. Lajes, Coxilha Rica, 6 January 1946, Swallen 8173 (holotype, US!) $=P$. coryphaeum, syn. nov.

The only difference between this variety and the typical one is the glabrous condition of the lower blades and a smaller inflorescence (ca. $14 \mathrm{~cm}$ long). These features put it precisely within the range of morphological variation of $P$. coryphaeum.

12. Paspalum vescum Swallen, Phytologia 14: 364. 1967.

Type. Brazil: Minas Gerais, Uberlandia [Uberlândia], 15 March 1930, A. Chase 11259 (holotype US 1448779!; fragment MO!).

The holotype is represented by a perennial plant, with culms $35-40 \mathrm{~cm}$ tall, blades setaceous, $5-15 \mathrm{~cm}$ long and ca. $1 \mathrm{~mm}$ wide. Each culm bears a single terminal raceme, $1.5-3 \mathrm{~cm}$ long. The spikelets are paired, one often underdeveloped (occasionally threre is a solitary spilkelet due to the abortion of one of the pair), ca. $2 \mathrm{~mm}$ long, glabrous. 
There is a detailed English description and an adequate Latin diagnosis of this species in Chase's unpublished MS on Paspalum of South America at US under the name "Paspalum vescum Chase, sp. nov." The "type" cited by Chase is the same as Swallen's holotype but the English description and the Latin diagnosis are not the same. Chase assigned her species to the Recta group whereas SWALLEN (1967) put his in Linearia.

This species is close to $P$. crispulum Swallen, from which it is distinguished by possessing a single raceme, glabrous at the base, and paired spikelet. The collector of the type specimen apparently observed some variation in raceme number in the field, because she wrote on the label : "[raceme] solitary, rarely paired," but no paired racemes are to be found in the type collection. Irwin et al. 9810 (MO) and Filgueiras 1146 (IBGE, MO, SP), both from Central Brazil, have plants with one and two racemes, but these are not conjugate. In the paired racemes the lower spikelets are solitary, and the rest paired. If conjugate racemes are ever found within the population of $P$. vescum, then the relationship between these two species must to be re-evaluated again.

13. Paspalum crispulum Swallen, Phytologia 14: 365. 1967.

Type. Brazil: Goiás, Niquelândia, Macido [Macedo], 25 February 1956, A. Macedo 4432 (holotype US 2208290!).

The holotype is a plant densely caespitose, with culms $22-35 \mathrm{~cm}$ tall, the blades are setaceous, $6-10 \mathrm{~cm}$ long and ca. $1 \mathrm{~mm}$ wide. Racemes 2 , conjugate; the spikelets are solitary, 1.9 - $2 \mathrm{~mm}$ long, elliptic, glabrous. As noted before, this species is hardly distinguishable from $P$. vescum. In Filgueiras 2467 (IBGE, MO, SP) all the plants have only 2 conjugate racemes but in Irwin \& Soderstrom 7648 (UB) there is a culm with 2 conjugate racemes and another culm with 2 conjugate racemes plus a third one below. In both collections, the spikelets are solitary. P. crispulum is known only from the serpentine outcrops of Niquelânia, in the Brazilian state of Goiás. Paspalum pulchellum Kunth, a similar species with setaceous blades and 2 (occasionally 3 ) racemes, is distinguishable from $P$. crispulum because in that species the racemes are not conjugate and the upper glume is missing, thus leaving the upper lemma exposed.

14. Paspalum pallens Swallen, Phytologia 14: 365. 1967.

Type. Brazil: Minas Gerais, Ituiutaba, Santa Terezinha, 18 February 1950, A. Macedo 2167 (holotype US 1982916!).

This species is similar to $P$. minarum Hack. but it differs in its obligatory aquatic habitat, longer spikelets $(3.3-3.5 \times 1.1-1.2 \mathrm{~mm})$ and papillose upper floret.

15. Paspalum fessum Swallen, Phytologia 14: 366. 1967.

Type. Brazil: Minas Gerais, Ituiutaba, Praião, 3 September 1950, A. Macedo 2543 (holotype US!; isotype $\mathrm{MO} !=P$. pallens Swallen, syn. nov. 
The original Latin description (SWALLEN, 1967) states that the culms are "erecti", but the English version describes them as "erect from an ascending base", which agrees with the decumbent culm of the holotype. Critical comparison of the types of $P$. pallens and $P$. fessum, together with the original descriptions, point to the following differences between them:

$P$. pallens, habitat aquatic, culms erect, lower blades densely hairy on the adaxial surface and $P$. fessum, habitat sandy soil on river banks, culms decumbent, lower blades glabrescent, with decidous hairs, which gives the adaxial surface of the blade a rough appearence. I believe that $P$. fessum is a terrestrial form of $P$. pallens. It is possible that intermeadiate forms exist in nature, but they have not been documented. Aquatic grasses can occasionally grow on river or lake banks, and when it happens, the plants exhibit a slightly distinct morphology to cope with a different ecological situation. This is probably what happens with $\mathrm{P}$. pallens.

\section{Paspalum ambustum} Swallen, Phytologia 14: 366, 1967.

Type. Brazil: Paraná, Ponta Grossa, Estação Experimental, 5 February 1946, J.R. Swallen 8466 (holotype US $1961593 !=P$. riedelii Mez, fide Renvoize, 1988.

The original description of $P$. riedellii (Mez, 1918) and the fragment of the type specimen at US (RIEDEL, 1645) agree with the description and the holotype of $P$. ambustum. The inflorescence of the latter seems to have been not totally exserted when the plant was collected and was described by SWALLEN (1967) as partially enclosed by the uppermost sheath. The inflorescence of $P$. riedellii was described by MEZ (1918) as "folia longe superans."

SWALLEN (1967) did not reveal whether the plant he collected at the Ponta Crossa Experimental station was under cultivation or growing naturally on the grounds. However, as it was collected in a "banhado", i.e., a wet or boggy place, it is fairly safe to assume that it was growing spontaneously on the grounds of that research station. RENVOIZE (1988) reports a similar habitat (swampy ground) for the species in the states of Minas Gerais and Paraná (Brazil) and in Paraguay

17. Paspalum album Swallen, Phytologia 14: 367. 1967.

Type. Brazil: Minas Gerais. Diamantina, Serra de San [Santo] Antonio [Antônio], 27-30 December 1929, A. Chase 10397 (holotype US 1500420!)

This species is closely related to $P$. erianthoides Lindm. from which if differs by the bearded nodes and absence of long, colorless hairs on the ligular region. According to the original description, the most distinctive characteristic of this species is the involute blades. In fact, most of the blades on the holotype are involute, but a few are flat, long and narrow, i.e., 10 $-17 \times 0.1-0.2 \mathrm{~cm}$. SWALLEN (1967) refers to some cauline leaf blades being as much as $45 \mathrm{~cm}$ long. Such long blades could not be found in the type 
material examined. The holotype was apparently collected just after a fire because it shows clear signs of having being recently burnt. This might have effected the growth habit of the plants, as it is often the case with other grass species from open habitats of Central Brazil.

The densely villous spikelets are indistinguishable from those of $P$. erianthoides, $P$, erianthum Nees ex Trin. and $P$. sanguinolenteum Trin. SENDULSKY \& BURMAN (1978) refered to the fact that the latter species often displays spikelets with a lower glume, a condition never found in $P$ album.

18. Paspalum diamantinum Swallen, Phytologia 14: 368. 1967.

Type. Brazil: Minas Gerais, Diamantina, Serra de San [Santo] Antonio [Antônio], 27-30 December 1929, A. Chase 10401 (holotype US?, n.v.).

Neither the holotype nor the paratype of $P$. diamantinum cited by SWALLEN (1967) were found at US. According to staff members, the holotype is "missing, temporarily misplaced."

SWALLEN (1967) compared $P$. diamantinum to $P$. ammodes Trin, but the protologue suggests a closer relationshiop to $P$. erianthoides because of the long, narrow blades, 7- 26 $x 0.1 \mathrm{~cm}$, inflorescence of $3-5$ ascending racemes, $7-9 \mathrm{~cm}$ long, spikelets $3.6-3.8 \mathrm{~mm}$ long, upper glume and lower lemma 5-nerved, villous. The only appreciable difference between those two species is the leaf vestiture, which in $P$. diamantinum was described (SWALLEN, 1967) as "pubescent or pilose on the upper surface, or glabrous toward the tip, glabrous beneath," whereas in P. erianthoides the leaves were described as being entirely glabrous (LINDMAN, 1900; SMITH et al., 1982). Because the type collection of $P$. diamantinum could not be located, this species is here considered doubtful, but it is very likely that it is a slight morphological variation of $\mathrm{P}$. erianthoides.

19. Paspalum involutum Swallen, Phytologia 14: 368. 1967.

Type. Brazil: Minas Gerais, Diamantina, Serra de San [Santo] Antonio [Antônio], 27-30 December 1929, A. Chase 10400 (holotype, US 1500757 !), Syn. nov. $=P$. album Swallen.

The holotype of this species is indistinguishable from that of $P$. album considering both vegetative and reproductive strutures. The holotypes of both names came from the same locality (Serra de Santo Antonio) in the Brazilian state of Minas Gerais, and were collected during the same period (27-30 December 1929). As the collector's numbers are very close (Chase 10397 and 10400) it is possible that the two populations sampled by Chase were situated close to each other, or both plants could even have come from the same population.

20. Paspalum mollifolium Swallen, Phytologia 14: 369. 1967.

Type. Brazil: Minas Gerais, near Faria, Serra da Bocaina, 6 January 1930, 
A.Chase 10522 (holotype US 1500690!), Syn. nov. $=P$. sanguinolenteum Trin .

The holotype of this species is morphologically very close to plants of $P$. sanguinolenteum making them unseparable, i.e., leaf blades are 10$15 \times 0.2-0.5 \mathrm{~cm}$ and densely pilose on both surfaces. The hairs on the blades of $P$. mollifolium, however, are very soft, whereas those of typical $P$. sanguinolenteum are tough or hispid. Since no other reliable morphological characteristic was found to consistently separate them, $P$. mollifolium is here put into synonymy.

21. Paspalum rigens Swallen, Phytologia 14: 369. 1967.

Type. Brazil: Minas Gerais, 5-10 $\mathrm{km} \mathrm{W}$ of Diamantina, Serra de San [Santo] Antonio [Antônio], 27-30 December 1929, A. Chase 10442 (holotype US !), Syn. nov. $=P$. erianthum.

The holotype is a very typical plant of P.erianthum with blades $9-17 \times 0.3$ $-0.5 \mathrm{~cm}$, glabrescent, 3 - 5 racemes, 6 $8 \mathrm{~cm}$ long, spikelets $3.5-4.2 \mathrm{~mm}$, villous.

22. Paspahum intonsum Swallen, Phytologia 14: 370. 1967.

Type. Brazil: Minas Gerais, Hargreaves, 21-22 December 1929 , A.Chase 10268 1/2 (holotype US 1501433 !), Syn. nov. $=P$, erianthum .

The holotype is a typical plant of P. erianthum, with leaf blades $15-25$ $x 0.3-0.7 \mathrm{~cm}$, pilose to villous on both surfaces. The spikelets are $3.5-4.4$ $\mathrm{mm}$ long, densely villous. The specific epithet apparently refers to the hairy ("unshaved") condition of the leaves.
Morphologically this species is inseparable from plants of $\mathrm{P}$. erianthum.

23. Paspalum haughtii Swallen, Phytologia 14: 370. 1967.

Type. Colombia: Los Lhanos, Comisaria EI Vichada, O. Haught 2771 (holotype US 1706822!), Syn. nov. = $P$. erianthum.

Although the holotype of $\mathrm{P}$. haughtii is from Colombia. Swallen (1967) cited an additional collection from $\mathrm{Ma}^{+} 0$ Grosso, Brazil, J T. Baldwin 3077(US!). which matches the plants of $P$. erianthum.

The holotype of $P$. haughtii can be referred to as a rather robust specimen of P. erianthum. with culms 125 - $134 \mathrm{~cm}$ tall, blades $15-25 \times 1-1.1$ $\mathrm{cm}$, glabrescent to pilose on both surfaces. The villous condition of the basal leaves referred to by Swallen (1967) is also found in plants of $P$. erianthum throughout its range (e.g. Hatschbach 35422, MO; IRWIN et al. 9603, MO). The degree of morphological variation in this species is remarkable and is demonstrated by the following selected specimens: Irwin et al. 9603 (Distrito Federal, Brazil); nodes pilose, sheaths villous, blades $10-22$ x $0.5-1 \mathrm{~cm}$, villous; Killeen 2779 (Santa Cruz, Bolivia): nodes pilose, sheaths glabrous, blades $11.5-20.6 \mathrm{x}$ $0.5-1.5 \mathrm{~cm}$, glabrous; Macedo 1401 (Minas Gerais, Brazil): nodes pilose, sheaths glabrescent, blades $14-14.5$ x $1.2-1.4 \mathrm{~cm}$, glabrous, with ciliate margins; Harley 10495 (Mato Grosso, Brazil): nodes pilose to glabrescent, sheaths glabrescent, blades $15-39 \mathrm{x}$ $1-2 \mathrm{~cm}$, glabrous; Chase 10244 (Bra- 
zil, Minas Gerais): nodes pilose, glabrescent to glabrous, sheaths glabrescent, blades $20-25.6 \times 0.2-0.6 \mathrm{~cm}$. glabrescent.

24. Paspalum sericatum Swallen, Phytologia 14: 371, 1967.

Type. Brazil: Minas Gerais, Serra do Cipó. Chapeo [Chapéu] de Sol, 28 March-1 April 1925, A. Chase 9213 (holotype US 1255284!), Syn. nov $=P$. sanguineolentum Trin. The holotype of P.sericatum is a plant that matches the description of $P$. sanguineolentum with mostly basal leaves, $5-12 \times 0.2-0.3 \mathrm{~cm}$, glabrescent on both surfaces. In addition to the holotype, two of the three paratypes cited by SWALLEN (1967) were also examined at US, Chase 10315 and Glaziou 16558, both from Minas Gerais. Chase 10315 has plants with 2 - 3 racemes, whereas Glaziou 16556 has one plant with 4 racemes. In both collections the blades are $6-10 \times 0.2$ $-0.3 \mathrm{~cm}$, pubescent. Morphologically $P$ sericatum is indistinguisable from $P$. sanguineolentum.

25. P, paucifolium Swallen, Phytologia 14: 372. 1967.

Type. Brazil: State or locality not given; date not given, J.R. Swallen s.n. (US 1258166!).

The holotype is a poor specimen problably taken from a larger clump which was dug and then divided into smaller units. The robust rhizome system is the most distinctive feature of this specimen. The leaf blades are linear-lanceolate, $4-8 \times 0.3-0.5 \mathrm{~cm}$, pilose on both surfaces.
This species is scarcely distinguishable from, if not conspecifc with $P$. sanguineolentum. BURKART (1969) and SMITH et al. (1982) suggested a close relationship to $P$. erianthum, but examination of the holotype points to a closer affinity with $P$. sanguineolentum because of the leaf blade size and presence of an occasional lower glume on the spikelet. This structure, never mentioned by SWALLEN (1967) is also refered to by BURKART (1969). Its description matches the illustration (fig. $6 \mathrm{~b}$, c) of SENDULSKY \& BURMAN (1978) for P. sanguineolentum.

Paspalum paucifolium is here maintained as a distinct species because of its well developed rhizome system and solitary spikelets on the rhachis.

26. Paspalum formosulum Swallen. Phytologia 14:372. 1967.

Type. Brazil: Minas Gerais, Hargreaves, 21-22 December 1929. A. Chase 10226 (holotype US 1501432), Syn. nov. $=P$. sanguinolenteum Trin.

The holotype is a plant with culms $55-65 \mathrm{~cm}$ tall, blades $7-14 \times 0.3-0.5$ $\mathrm{cm}$, densely pilose on both surfaces, 3 5 racemes, also densely pilose. This specimen falls into the range of morphological variation of $P$. sanguinoleneum.

28. Paspalum luticulum Swallen, Phytologia 14: 373. 1967.

Type. Brazil: Pará, Maicurú [Maicuru], Lago Uruxiacá 16 June 1952, J.M. Pires \& N.T. Silva 4298 (holotype US 2205852!; isotype C, n.v.) = P. wrightii Hitchc. \& Chase, fide Killeen, 1990; Judziewicz, 1990. 
The holotype is a tall plant of 140 - $160 \mathrm{~cm}$, with spongy culms, and somewhat hispid leaves. It matches the description of $P$. wrightii, a species of ample distribution, from Cuba, Venezuela, Guyana, Bolivia, Paraguay and Brazil.

30. Paspalum lacustre Chase ex Swallen, Phytologia 14: 374. 1967. Type. Brazil: Amapá, Municipio de Macapá; Ambé, localidade no afluente do Rio Pedreira, 8 July 1951, R.L. Fróes \& G.A. Black 27312 (holotype, IAN $64326 \mathrm{n.v}$.; isotype US!: fragment US!).

This is an aquatic species with floating culms. It is morphologically closely related to Paspalum commutatum Nees from which it differs by the narrowly elliptic spikelets and pale, opaque upper floret, versus the broadly ovate spikelets with a dark brown upper floret of $P$. commulatum. The glume and sterile lemma of $P$. lacustre are described in the protologue as 3-nerved, however the spikelets in the isotype and in the fragment at US, are all 5-nerved.

29. Paspalum cordaense Swallen, Phytologia 14: 374. 1967.

Type. Brazil: Maranhão, Barra do Corda to Grajahú [Grajaú], 1-5 March 1934, J.R. Swallen 3618 (holotype US 2238395, "missing, temporarily misplaced.")

The status of this name remains doubtful because the type collection could not be found at US. The protologue, however, describes a plant with a combination of features that ren- ders the species unique, such as annual habit. ligule decurrent. $3 \mathrm{~mm}$ long. blades $8-25 \times 0.4-0.6 \mathrm{~cm}$, inflorescence of 2 racemes, spikelets densely hairy, lower lemma with various brown spots, upper lemma with a conspicuous "hump" in the centre.

37. Paspalum guaricense Swallen, Phytologia 14: 378. 1967.

Type. Venezuela: Guarico. El Dividive, 11 September 1927, H. Pittier 12520 (holotype US 1343986!).

The type of this names is from Venezuela. As the species has never been collected in Brazil. it will not be treated here.

44.Paspalum compressifolium Swallen, Phytologia 14: 381, 1967. Type. Brazil: Rio Grande do Sul, Passo Fundo, Fazenda da Brigada, margin of banhado, 19 December 1945, J.R Swallen 7790 (holotype US 1961358!) $=P$. lenticulare, fide Killeen, 1990.

The holotype is a plant with conduplicate, glaucous, glabrous leafblades which gives the plant an equitant appearance. It was synonymized under $P$. plicatulum Michx. by RENVOIZE (1988) but in agreement with KILLEEN (1990) it is here maintained in the synonymy of $P$. lenticulare because of the conspiciously compressed leaves and the spikelet structure. The degree of leaf compression varies, however, among the paratypes cited by SWALLEN (1967), e.g. , Swallen 8318, Reitz \& Klein 14146 (US), all from Brazil. The same pattern of variation can be found in specimens from 
Santa Cruz, Bolivia, e.g. , Killeen 2396, 858, 1838 (MO).

47. Paspalum oteroi Swallen, Phytologia 14: 383. 1967.

Type. Brazil: Rio de Janeiro, [Deodoro], Seccão [Seção] Experimental de Agrostologia, grown from "seed" collected in the Pantanal, Mato Grosso, 15 Fabruary 1950, J.R. Otero s.n. (holotype US 1982726!).

The holotype is a plant with decumbent culms, rooting at the lower nodes. The spikelets are $2.5-3.3 \mathrm{~mm}$ long with upper glume and lower lemma densely pubescent. Recent gatherings (e.g., Allem \& Vieira 1344, 1386 ) indicate that this species is abundant in the Brazilian state of Mato Grosso, has extensive stolons and is a distinct member of the Plicatula group. It was described as excellent native fodder (ALLEM \& VALLS, 1987).

48. Paspalum planiusculum Swallen, Phytologia 14: 384, 1967.

Type. Brazil: Maranhão, between Grajahú [Grajaú] and Porto Franco, 813 March 1934, J.R.Swallen 3841 (holotype US 1613026!), Syn, nov: $=P$. malacophyllum Trin.

The holotype is a perennial plant, typical of $P$. malacophyllum. The flattened nature of the culms refered to by SWALLEN (1967) as an autopomorphic character for this species is artefact probably originating when the somewhat spongy culms were pressed during the drying process. The blades are pseudopetiolate, $15-30 \times 1.4-2.0 \mathrm{~cm}$, glabrescent to pilose. Leaf blades measuring as much as $60 \mathrm{~cm}$ long were described in the protologue, but they are not present on the holotype. The inflorescence are $25-35 \mathrm{~cm}$ long with inumerous ascending racemes.

49. Paspalum tenuifolium Swallen, Phytologia 384. 1967.

Type. Brazil: Maranhão, between Caxias to Barra do Corda, 18-26 February 1934, J.R. Swallen 3602 (holotype US 1612692!), Syn. nov. $=P$. malacophyllum Trin.

The holotype is a robust plant of indefinite duration, although the protologue described it as annual. The leaf blades are $20-40 \times 1.2-2 \mathrm{~cm}$, glabrescent, thin. Morphologically it is indistinguishable from other specimens of $P$. malacophyllum from Brazil, such as Irwin et al. 15249, 27288 (MO) and Plowman et al. 8529 (MO).

50. Paspalum costellatum Swallen, Phytologia 14: 385. 1967.

Type. Brazil: Maranhão, Carolina to San [Santo] Antonio [Antônio] de Balsas, 20-25 March 1934, J.R. Swallen 3955 (holotype US 1613883!).

The holotype is a slender annual with culms branching at the base, 12 $20 \mathrm{~cm}$ long. The leaf-blades are $4-6$ x $0.4-.0 .8 \mathrm{~cm}$, glabrescent, inflorescence terminal and axillary, racemes 3 -6 , spreading, $2.3-2.7 \mathrm{~cm}$ long. This species is similar to $P$. malacophyllum but is distinguished by its true annual habit, slender culms, branching at the base, and the presence of an axillary inflorescence.

51. Paspalum eitenii Swallen, Phytologia 14: 385, 1967.

Type. Brazil: Maranhão, Municipio [Município] de Loreto, be- 
tween Rios Balsas and Parnaiba, "Ilha de Balsas" region, 6 April 1962, G. Eiten \& L.T. Eiten 4091 (holotype US 2434291 !) $=$ P. malacophyllum Trin., syn. nov.

The holotype is a plant of indefinite duration that matches the description of $P$. malacophyllum except for slender culms. The protologue describes the plant as an annual, but this is not easily verifiable, as it can easily be classified either as a weak perennial that grew in unfavourable conditions or as an annual that grew in a more favourable site. No diffence was found in the reproductive structures between $P$. eitenii and $P$. malocophyllum.

Paspalum malacophyllum is variable in a series of charactersitcs, such as robustness, node pubescence, leaf pubescence, inflorescence size, raceme number and raceme size. The following selected specimens exemplify the continuous pattern of morphological variation: Swallen 3969 (US), weak perennial (appearing annual); Plowman et al. 8778, 8529 (MO), robust perennial; Chase 8791 (US), glabrous nodes; Irwin et al. 16388 (US), glabrescent to pilose nodes; Chase 9258 (US) glabrous and pilose nodes; Quevedo \& Centurión 474 (MO), glabrous blades; Plowman et al. 8529 (MO), inflorescence with less than 20 racemes; Quevedo \& Centurión 474 (MO), inflorescence with more than 50 racemes. The specimen Chase 9258 (US) is especially intriguing because it has racemes bearing spikelets from the base to the apex as well as some racemes without spikelets at the base, which gives these racemes a "naked" appearance. Chase 8892 (US) has typically pyramidal inflorescences.

52. Paspalum clandestinum Swallen, Phytologia 14: 386, 1967.

Type. Brazil: Maranhão, between Carolina and San [Santo] Antonio [Antônio] de Balsas, 20-25 March 1934, J.R. Swallen 4064 (holotype US 1613861!).

Paspalum clandestinum is a distinctive spccies in the Decumbentia group, apparently closely ralated to $P$. ekmanianum Henr. because of the solitary raceme, pilose spikelets, spotted, pilose glume and lower lemma, and smooth, shining upper lemma, but differing by its annual habit, and the presence of a lower glume. It is also similar to $P$. pilosum Lam., but differing by its spotted glume and lower lemma and smooth, shining upper lemma, in contrast to the evenly papillose lemma of P. pilosum. This species is known only from the type collection.

53. Paspalum schultesii Swallen, Phytologia 14: 387. 1967.

Type. Colombia: Vaupés, near Rio Paraná Pichuna, June, 1953, R.E. Schultes \& I.Cabrera 19934 (holotype US!; isotype MO!).

The type of this name was collected in Vaupés, Colombia. As the species has never been collected in Brazil, it is not treated here.

\section{Paspalum froesianum} Swallen, Phytologia 14: 387. 1967.

Type. Brazil: Amapá, km 120 of the Macapá-Chevelândia road, 22 July 1951, G.A. Black \& R.L. Froés 51- 
12357 (holotype US 2205975!) $=P$ loefgrenii Ekman, fide Renvoize, 1984; Judziewicz, 1990.

The holotype of $P$, froesianum matches the description and holotype of $P$. loefgrenii in every respect. This is a robust plant with curled basal leaves. $P$. loefgrenii has been collected in several places in the state of Bahia but the holotype (Loefgren 721, US !) comes from "Serra Camará, Ceará." The occurence of this species in the state of Amapá greatly extends its previously known range.

55. Paspalum telmatum Swallen (as "Paspalum telmatus"), Phytologia 14 388. 1967. Type. Brazil: Mato Grosso [Mato Grosso do Sul], Lagoinhas, between Campo Grande and Dourados, A Chase 10926 (holotype US 1500550!). Syn. nov. $=P$. malacophyllum .

The holotype is extremely similar to that of $P$. planiusculum Swallen with compressed leaf blades, blades 20 - 30 x $0.3-0.8 \mathrm{~cm}$, densely pilose. No consistent characteristic was found to separate it from $P$. malacophylhum and it is, therefore, put in synonymy of the latter. Leaf pubescence in $P$. malacophyllum as noted before, is highly variable.

56. Paspalum redondense Swallen, Phytologia 14: 388. 1967.

Type. Brazil: Paraná, Guarapuava. Fazenda Capão Redondo, 20-23 March 1946, J.R. Swallen 8837 (holotype US 1961595!), Syn. nov. $=P$. indecorum Mez.

The holotype of this name matches the description of $P$. indecorum on the thick, almost corm-like rhizome base, blades flat, $60-120 \times 1.5$
$-2.5 \mathrm{~mm}$, racemes $4-6,5-9 \mathrm{~cm}$ long, and all the spikelet features, except the number of nerves of the glume and lower lemma, 3 - 5. Some collections from Argentina (e.g. Montes 15327, 10807, Renvoize et al. 3024 (MO) indicate that this species varies in a number of characteristics, such as leaf size and vestiture, raceme number, spikelet size, number of nerves on glume and lower lemma $(3-5)$. It occurs in Argentina (Missiones). Brazil (Paraná, Santa Catarina, Rio Grande do Sul) and Uruguay As no appreciable difference was found to separate the types of these two names, they are here merged.

57. Paspalum morulum Swallen, Phytologia 14: 389. 1967.

Type. Brazil: Maranhão, from Loreto to Fazenda Aldeia, 11 April 1962, G.Eiten \& L. T. Eiten 4250 (holotype US 2434293!).

A distinctive species in the Plicatula group, characterized by its annual habit, solitaray spikelet, mottled glume and lower lemma, and pale, smooth upper floret. Paspalum pannuceum Swallen also has mottled glume and lower lemma, but it also has culms to $2.3 \mathrm{~m}$ tall, membranous ligules ca. $3 \mathrm{~mm}$ long, and dark, papillose upper florets. Paspalum marmoratum Kuhlm. a similar species, differs by having glume and lower lemma smaller than the upper floret and exposed, marmorate upper floret.

58. Paspalum swallenii Chase ex Swallen, Phytologia 14: 389. 1967. Type. Brazil: Maranhão, between Carolina and San [Santo] Antonio 
[Antônio] de Balsas, 20-25 March 1934, J.R. Swallen 4100 (holotype US 2238406; isotype US!), Syn. nov. $=P$. morulum Swallen.

The description of this species was based on a specimen of $P$. morulum with smaller racemes and spikelets. The holotype agrees entirely with the original description and holotype of $P$. morulum, except that the racemes are $1-2 \mathrm{~cm}$ long and the spikelets $1-1.2 \mathrm{~mm}$ long. These size differences overlap with those of $P$. morulum. Since both species were described in the same publication, the principle of priority is not applicable until one is selected. The name $P$. morulum was chosen because in this author's opinion, it is a befitting epithet for the species which has dark coloured upper floret.

\section{ACKNOWLEDGEMENTS}

I thank Drs. D. Nicolson, J.H. Kirkbride, Jr. and Gerrit Davidse for critical comments on the manuscript. Also two anonymous reviewers made helfull suggestions. CAPES and $\mathrm{CNPq}$ financed part of this study. I especially thank the USDA-Forest Service (Drs. Diane Bellis and Philipp Higgins) for financing my trip to Washington, D.C. to work at the Smithsonian Institution. I am indebted to Dr. Paul Peterson and his staff at US who provided all the facilities I needed to carry on my research there. I also thank the Missouri Botanical Garden for making their research facilities available to me. Special thanks go to Mr. Clarence J.
Lovejoy Jr. and family for their friendship and support during my stay in Saint Louis, Missouri.

\section{Literature Cited}

ALLEN, A. \& VALLS, J.F.M. 1987. Recursos forrageiros nativos do pantanal matogrossense. EMBRAPA-CENARGEN, Brasilia

BURKART, A. 1969. Flora Ilustrada de Entre Rios: gramineas, la familia botánica de los pastos. INTA, Colección científica v.6, pt. 2, Buenos Aires.

HOLMGREN, P.K., HOLMGREN, N.H. \& Barnett, L.C. 1990. Index Herbariorum. Part I: Herbaria of the World. 8th Ed., New York Botanical Garden, New York.

JUDZIEWICZ, J. 1990 [1991]. Poaceae (Gramineae). In: Flora of the Guianas. A.R.A. GORTS-VAN RIJN (ed.). Koeltz Scientific Books, Koenigstein.

KILLEEN, T, J. 1990. The grasses of Chiquitania, Santa Cruz, Bolivia. Ann. Missouri Bot. Gard. 77: 125-201.

LINDMAN, C.A.M. 1900. Beitrage zur Gramineenflora Sudamerikas. Neue oder weniger bekannte Gramineen. Kongl. Svenska Vatenskapsakad. Handl., 34: 26

RENVOIZE, S.A. 1984. The grasses of Bahia. Royal Botanic Gardens, Kew.

1988. Hatschbach's Parana grasses. Royal Botanic Gardens, Kew.

SENDULSKY, T. \& BURMAN, A.G. 1978. Paspalum species of the Serra do Cipó (I): a contribution to the study of the Brazilian Poaceae. Revta. Bras. Bot. 1: $1-15$.

SMITH, L.B., WASSHAUSEN, D. C. \& KLEIN, R.M. 1982. Gramineas. In: REITZ, R. (ed.) Flora llustrada Catarinense, I., 85. Paspalum-115. Zea, Herbário Barbosa Rodrigues, Itajaí.

SWALLEN, J.R. 1967. New species of Paspalum. Phytologia 14: 358-389. 
TRINIUS, C B. 1826. De Graminibus paniceis, Petropoli [St. Petersburg]. Impensis Academiae Imperialis scientiarum.
1829. Species graminum. Petropoli [St. Petersburg]: vol. 2, Impensis Academiae Imperialis scientiarum.

Aceito para publicação em 29/12/93 